\title{
A Literature Review on the Role of Religiosity in Islamic Banking Adoption
}

\author{
Umda Nafia Yasin ${ }^{1, a}$ and Sri Rahayu Hijrah Hati ${ }^{b^{*}}$ \\ ${ }^{1}$ Islamic Business Undergraduate Program Faculty of Economics and Business Universitas \\ Indonesia-Depok, Indonesia \\ ${ }^{2}$ Management Department Faculty of Economics and Business Universitas Indonesia-Depok, \\ Indonesia \\ aumda.nafia@ui.ac.id, bsri.rahayu72@ui.ac.id \\ ${ }^{*}$ Corresponding author
}

Keywords: Religiosity, adoption, Islamic Banking, literature review

Abstract. Despite the exponential growth in the Muslim population across the world, a large gap still exists between the number of existing customers of Islamic banking and the number of potential customers. Previous and numerous studies in the field of consumer research have demonstrated the associations among religious affiliation, religiosity, consumer life style, and consumer behavior. The current study aims to examine the role of religiosity in the adoption of Islamic banking among Muslim customers. A literature review shows mixed results regarding the role of religiosity in the adoption of Islamic banking.

\section{Introduction}

With the development trend among the global Muslim population tending to increase, the market for Islamic banking has also increased. However, unfortunately, the gap between the existing customers and potential customers served by Islamic banks is still quite large. According to the Annual Report 2016 Ernst \& Young Islamic Banking Industry [1], Islamic banks had served 100 billion consumers globally by the end of 2015. However, the potential market is estimated to be six times larger than the existing customer base. As previous studies have proven that religiosity has a significantly influence on consumer behavior in making decisions, the researchers examine the role of religiosity in the adoption of Islamic banking by potential consumers.

\section{Literature review}

\subsection{Islamic Banking and Religiosity Definition}

'Islamic bank' refers to a bank conducting business based on Islamic principles, without interest or other fixed rates of return, that has the characteristic of risk sharing among investors, banks, and users of funds [2]. In this study, religiosity is defined as the extent to which an individual is committed to his or her religion and religion is reflected in the individual's attitudes and behavior [3]

\subsection{Customer adoption}

Adoption refers to a person's decision to become a regular user of a product; adoption is followed by a process of becoming a loyal customer [4]. The adoption process can be influenced by the following factors: consumer readiness to try new products, the personal character of the consumer, relative advantage, compatibility, complexity, divisibility or trialability, communicability or observability, costs related to the product, the risk of uncertainty, credibility, community recognition, and the character of the product or innovation [4]. These factors influence the adoption of Islamic banking among Muslim consumers [5]. 


\section{Method}

To classify the literature relating to religiosity and Islamic banking adoption, the researchers searched articles via Google Scholars and the ProQuest database. Various relevant key terms were used, such as Islam, Islamic, religion, religiosity, and adoption. The identified articles were restricted to peer-reviewed journals. Thirteen articles which discuss the role of religiosity in Islamic banking adoption were found and analyzed further.

\section{Analysis}

\subsection{The Significant Influence of Religiosity in Islamic Banking Adoption}

Based on the literature review, religiosity has a significant influence on the attitude toward Islamic banking [6] and Islamic banking adoption [7]-[10]. Despite the important role of religiosity in the adoption of Islamic banking, one study shows that Islamic compliance of the Islamic bank, or halalness, is the first criterion for choosing an Islamic bank, showing the high value customers put on religion [8]. Of note is that profitability is the second criterion for consumers in choosing an Islamic bank [8].

Table 1. Significant Influence of Religiosity

\begin{tabular}{|c|c|c|c|}
\hline Results & Method & Country & References \\
\hline $\begin{array}{l}\text { Religiousity influences Islamic banking adoption } \\
\text { and is moderated by education and maturity. }\end{array}$ & $\begin{array}{c}\text { Survey of } 334 \text { Malay } \\
\text { Muslims }\end{array}$ & Malaysia & [7] \\
\hline $\begin{array}{l}\text { Religiosity has a great effect on the attitude toward } \\
\text { Islamic banking and is moderated by age, gender, } \\
\text { and income. }\end{array}$ & $\begin{array}{l}\text { In-depth interview with } 20 \\
\text { respondents and survey of } \\
400 \text { respondents }\end{array}$ & Egypt & [6] \\
\hline $\begin{array}{c}\text { Religiosity has a significant influence on Islamic } \\
\text { banking adoption. }\end{array}$ & $\begin{array}{l}\text { Survey of } 252 \text { banking } \\
\text { customers }\end{array}$ & Morocco & [9] \\
\hline $\begin{array}{c}\text { Religion, together with an awareness regarding } \\
\text { financial teachings of Islam, awareness regarding } \\
\text { Islamic bank products and services, advertising, } \\
\text { and networking influence the perception of Islamic } \\
\text { banks. }\end{array}$ & $\begin{array}{l}\text { Survey of } 150 \text { Muslim } \\
\text { respondents who are } \\
\text { customers of different } \\
\text { Islamic banks }\end{array}$ & Pakistan & [10] \\
\hline $\begin{array}{c}\text { Religiosity influences the consumer } \\
\text { decision-making process in choice of Islamic } \\
\text { banks. }\end{array}$ & $\begin{array}{l}\text { Survey of } 279 \text { of bank } \\
\text { depositors }\end{array}$ & Malaysia & [8] \\
\hline $\begin{array}{c}\text { Religious value is the most important factor in } \\
\text { Islamic bank patronage. }\end{array}$ & $\begin{array}{l}\text { Survey of } 250 \text { respondents } \\
\text { from Malaysian public } \\
\text { institutions } \\
\end{array}$ & Malaysia & [11] \\
\hline $\begin{array}{l}\text { Religious factors and convenient location are the } \\
\text { most important criteria for choosing an Islamic } \\
\text { bank. }\end{array}$ & $\begin{array}{l}200 \text { customers of full-pledge } \\
\text { Islamic banks }\end{array}$ & Pakistan & [12] \\
\hline $\begin{array}{l}\text { Religious preferences are the most important } \\
\text { criterias in selection between Islamic and } \\
\text { conventional banks. }\end{array}$ & Survey of 246 consumers & $\begin{array}{l}\text { United Arab } \\
\text { Emirates }\end{array}$ & [13] \\
\hline $\begin{array}{l}\text { Religious reasons are considerred along with bank } \\
\text { reputation, the effectiveness of transactions, } \\
\text { provision of privacy, and confidentiality. }\end{array}$ & $\begin{array}{l}\text { Survey of } 156 \text { consumers } \\
\text { from different cities in } \\
\text { Pakistan }\end{array}$ & Pakistan & {$[14]$} \\
\hline $\begin{array}{l}\text { Religious motivation is the driver in selection of an } \\
\text { Islamic bank. }\end{array}$ & $\begin{array}{c}\text { Mixed method research. } \\
\text { Survey of } 500 \text { customers and } \\
10 \text { semi-structured } \\
\text { interviews }\end{array}$ & Malaysia & {$[15]$} \\
\hline
\end{tabular}

Demographic variables such as age, income, gender, and education play a significant role in the relationship between religiosity and Islamic banking adoption [6], [7], [9]. In regard to age, the more mature the customer, the more religious the individual and the higher the probability of patronizing 
an Islamic bank [6], [7]. For gender, males and females have different degrees of religiosity as fewer females are religious while males are equally distributed in the low, moderate, and high religious group, showing a more positive attitude toward Islamic banking, especially in the male and highly religious group [6]. Another interesting result shows that despite the significant influence of religiosity on Islamic banks, most Muslim consumers still patronize conventional banks [7].

\subsection{Insignificant Influence of religiosity in Islamic Banking Adoption}

Despite the strong support for the role of religiosity in the adoption of Islamic banking, few scholars have documented this influence. Indeed, Muslim customers still place much higher importance on traditional criteria such as low service charge and service quality as the criteria upon which to choose a certain bank.

Table 2. Insignificant Influence of Religiosity

\begin{tabular}{cccc}
\hline Results & Method & Country & References \\
\hline $\begin{array}{c}\text { Fear, beliefs, and religious } \\
\begin{array}{c}\text { involvement have no direct effect } \\
\text { on intention. }\end{array}\end{array}$ & $\begin{array}{c}\text { Pretest of 188 respondents } \\
\text { and main survey of } 217 \\
\text { rerspondents }\end{array}$ & Tunisia & [16] \\
\hline $\begin{array}{c}\text { Low service charge is the top } \\
\text { criterion for customers. }\end{array}$ & $\begin{array}{c}\text { Survey of 156 Muslim and } \\
\text { non-Muslim respondents }\end{array}$ & United Kingdom & {$[17]$} \\
\hline $\begin{array}{c}\text { Service quality is more important } \\
\text { than religious belief in } \\
\text { influencing customers. }\end{array}$ & $\begin{array}{c}\text { Survey of 250 respondents } \\
\text { from four cities in Pakistan }\end{array}$ & Pakistan & {$[18]$} \\
\hline
\end{tabular}

\section{Summary}

The study shows mixed results regarding the influence of religiosity on Islamic banking adoption. However, based on the literature review, support is found for the positive influence of religiosity on the adoption of Islamic banking. Thus, the Islamic marketer can use religiosity as one basis for Islamic banking segmentation. However, it is worth noting that some Muslim customers still emphasize service quality, service charges, and other conventional criteria in choosing a bank. Future researchers should consider the differences in measurement used by previous researchers to evaluate religiosity and exercise caution in conducting research using religiosity as a variable and in drawing conclusions regarding religiosity.

\section{Acknowledgement}

This research was financially supported by a PITTA Grant to Directorate Research and Community Services Universitas Indonesia.

\section{References}

[1] EY, "World Islamic Banking Competitiveness Report 2016," 2016.

[2] M. Hoq, N. Sulatana, and M. Amin, "The Effect of Trust, Customer Satisfaction and Image on Customers' Loyalty in Islamic Banking Sector.," South asian J. Manag., vol. 17, no. 1, pp. 70-94, 2010.

[3] B. R. Johnson, S. J. Jang, D. B. Larson, and S. De Li, "Does Adolescent Religious Commitment Matter? A Reexamination of the Effects of Religiosity on Delinquency," J. Res. Crime nd Delinq., vol. 38, no. 1, pp. 22-44, 2001.

[4] P. Kotler and K. L. Keller, Marketing Management, 14th Edition, vol. 22, no. 4. 2012. 
[5] S. Thambiah, U. C. Eze, K. S. Tan, R. J. Nathan, and K. P. Lai, "Conceptual Framework for the Adoption of Islamic Retail Banking Services in Malaysia," J. Electron. Bank. Syst., vol. 2010, pp. 1-10, 2010.

[6] M. M. H. Abou-Youssef, W. Kortam, E. Abou-Aish, and N. El-Bassiouny, "Effects of religiosity on consumer attitudes toward Islamic banking in Egypt," Int. J. Bank Mark., vol. 33, no. 6, pp. 786-807, 2015.

[7] W. Marhaini Wan Ahmad, A. Ab Rahman, A. Che Seman, and N. Aini Ali, "Religiosity and Banking Selection Criteria Among Malays in Lembah Klang," Shariah J. J. Syariah Jil, vol. 16, no. 2, pp. 99-130, 2008.

[8] M. Abduh and M. A. Omar, "Islamic-Bank Selection Criteria in Malaysia: An AHP Approach,” Bus. Intell. J., vol. 5, no. 2, pp. 271-281, 2012.

[9] A. Echchabi and H. A. Aziz, "the Relationship Between Religiosity and Customers' Adoption of Islamic Banking Services in Morocco," Arab. J. Bus. Manag. Rev., vol. 1, pp. 89-94, 2010.

[10] N. Akhtar, M. T. Mehmood, M. Z. Pervez, F. Aslam, and H. Akhtar, "Factors Influencing the Perception of Customers in Islamic Banking: A Case Study in Pakistan," Int. Rev. Manag. Bus. Res., vol. 5, no. 3, pp. 844-859, 2016.

[11] A. R. Idris et al., "Religious Value as the Main Influencing Factor to Customers Patronizing Islamic Bank," World Appl. Sci. J. 12 (Special Issue Bols. Econ. Sustain., pp. 8-13, 2011.

[12] A. A. Rehman and O. Masood, "Why do customers patronize Islamic banks? A case study of Pakistan,” Qual. Res. Financ. Mark., vol. 4, no. 2/3, pp. 130-141, 2012.

[13] H. Sayani and H. Miniaoui, "Determinants of bank selection in the United Arab Emirates," Int. J. Bank Mark., vol. 31, no. 3, pp. 206-228, 2013.

[14] N. Azeem Khattak, "Customer satisfaction and awareness of Islamic banking system in Pakistan,” African J. Bus. Manag., vol. 4, no. 5, pp. 662-671, 2010.

[15] A. Echchabi and O. N. Olaniyi, "International Journal of Social Economics Malaysian consumers' preferences for Islamic banking attributes," Int. J. Soc. Econ. Nurdianawati Irwani Abdullah Int. J. Bank Mark. Iss Int. J. Bank Mark. Fadzlan Sufian Humanomics, vol. 39, no. 3, pp. 142-160, 2012.

[16] N. Souiden and Marzouki Rani, "Consumer attitudes and purchase intentions toward Islamic banks: the influence of religiosity," Int. J. Bank Mark., vol. 33, no. 2, pp. 143-161.

[17] W. Mansour, M. Ben Abdelhamid, O. Masood, and G. S. K. Niazi, "Islamic banking and customers' preferences: the case of the UK," Qual. Res. Financ. Mark., vol. 2, no. 3, pp. 185-199, 2010.

[18] H. M. Awan and K. S. Bukhari, "Customer's criteria for selecting an Islamic bank: evidence from Pakistan," J. Islam. Mark., vol. 2, no. 1, pp. 14-27, 2011. 